\title{
Twenty years on, the right of silence and legal advice: the spiralling costs of an unfair exchange
}

HANNAH QUIRK*

University of Manchester

\begin{abstract}
$\underline{\text { Abstract }}$
This article appraises the cumulative effects of the curtailment of the right of silence after 20 years. A controversial measure when enacted, its long-term effects have not been examined. It is argued that the Act was introduced on a flawed premise; has been interpreted very broadly; and has facilitated further restrictions on due process rights. Drawing upon the case law, academic commentary and empirical research, it is argued that the provisions have compromised the lanyer-client relationship and undermined the effectiveness of legal representation. Not only have the provisions made police interviews part of the trial (as Jackson argues), but they have also imported to the courtroom traditional police suspicions of defendants and their lawyers. The court has accordingly interpreted the provisions to the detriment of another 'fundamental condition'; legal professional privilege. The changes have thus had a wider impact than was envisaged at the time.
\end{abstract}

Key words: right of silence; police station legal representation; legal professional privilege; Court of Appeal

The right of silence and the legal representation of suspects had a special status in the

1 criminal justice system, described respectively as one the 'sacred cows'1 of British justice and 'one of the most important and fundamental rights of a citizen'. ${ }^{2}$ Both rights were also viewed with suspicion by some as a means by which 'criminals' could frustrate justice. Throughout most of the twentieth century, with some caveats, suspects were entitled to withhold their accounts from the police and also to decline to testify at trial; 3 a right controversially curtailed by ss 34-38 of the Criminal Justice and Public Order Act 1994 (CJPOA). The approaching 20th anniversary of this change, with concerns again being voiced

* Lecturer in Criminal Law and Justice, University of Manchester. I would like to thank David Hamer, Leonard Leigh, Roger Leng, Kieran McEvoy, John Murphy and Paul Roberts for their encouragement, advice and comments on drafts of this article.

1 A R N Cross, 'The Right to Silence and the Presumption of Innocence: Sacred Cows or Safeguards of Liberty' (1970-1971) 11 Journal of the Society of Public Teachers of Law 66-75.

2 R v Samuel [1988] 87 Cr App R 232, 245.

3 See P Mirfield, Silence, Confessions and Improperly Obtained Evidence (Oxford University Press 1998). 
about the possibility of miscarriages of justice, this time caused by the proposed cuts in legal aid, ${ }^{4}$ seems an appropriate juncture to examine the long-term effects of these changes.

The CJPOA permits prosecutorial and judicial comment and the drawing of 'such inferences as appear proper' when a defendant:

- relies at court upon any fact not mentioned during questioning or charge, that could reasonably have been raised at that stage (s 34);

- fails to account for the presence of any substance, object or mark on or in the suspect's person, clothing, footwear or possession (s 36); or his or her presence at a particular place (s 37);

- fails to testify or, having been sworn, refuses to answer questions without good cause (s 35).

The right of silence is often used, as here, as a convenient, if incomplete shorthand. 'It is important to remember that the significance of section 34 does not lie in silence in interview, it lies in reliance at trial on something that should have been said in interview. ${ }^{5} \mathrm{~A}$ police officer is 'entitled to question any person from whom he thinks useful information can be obtained ... A person's declaration that he is unwilling to reply does not alter this entitlement.' A suspect can be detained to 'secure or preserve evidence relating to an offence for which he is under arrest or to obtain such evidence by questioning him'. ${ }^{7}$ The police may take arrested suspects into custody in order to increase the likelihood of their answering questions, ${ }^{8}$ but suspects did not, ${ }^{9}$ and indeed do not, ${ }^{10}$ have to answer police questions. Suspects are cautioned when arrested and at the start of every interview: 'You do not have to say anything. But it may harm your defence if you do not mention when questioned something which you later rely on in Court. Anything you do say may be given in evidence.'11

The changes made by the CJPOA were justified partly as a trade-off against the improved rights provided for suspects by the Police and Criminal Evidence Act 1984 (PACE), in particular, the entitlement to free and independent legal advice at the police station. Although the right to consult a solicitor at an early stage of the investigation existed at common law, very few suspects actually exercised this right before PACE. Greer characterised this trade-off between the right of silence and improved protections as 'Exchange Abolitionism', 12 but this article argues that such an exchange was not fair and has cost suspects far more than was envisaged at the time.

4 'Legal Profession Joins Forces to Oppose Unreasonable Legal Aid Proposals' press release 14 May 2013 <www.barcouncil.org.uk/media-centre/news-and-press-releases/2013/may/legal-profession-joins-forces-tooppose-unreasonable-legal-aid-proposals/> accessed 25 May 2013; D Pannick, 'Why Chris Grayling Should Listen to the Evidence on Legal Aid: Miscarriages of Justice then Create Further Costs to the State' The Times (20 June 2013).

5 R $v$ Essa [2009] EWCA Crim 43, [15].

6 PACE Code $\mathrm{C}$, note $1 \mathrm{~K}$.

7 S 37(2) PACE.

8 Holgate-Mohammed v Duke [1984] AC 437; PACE Code C, Notes for Guidance 1B.

9 Rice v Connelly [1966] 2 QB 414.

10 There is no requirement to answer questions as there is, for instance, under pt XIV of the Companies Act 1985.

11 PACE Code C, 10.5.

12 S Greer, 'The Right to Silence: A Review of the Current Debate' (1990) 53(6) MLR 709-30. 
For such a contentious measure, there has been little investigation of the effects of the curtailment of the right of silence, ${ }^{13}$ and there appears little appetite for its restoration. ${ }^{14}$ Academic analysis focusing on the case-law initially described the changes as being of only 'marginal' evidential significance, ${ }^{15}$ or of greater burden than benefit to the prosecution. ${ }^{16}$ Little attention has been paid to the topic since the case-law became more settled. This contrasts with the impassioned debate when the CJPOA was enacted, when the right of silence was attacked for allowing experienced criminals to frustrate justice, and defended both as a protection against miscarriages of justice and as a signifier of the presumption of innocence. As Leng suggests, ${ }^{17}$ the almost exclusive focus on these polarised positions meant that insufficient attention was paid to other theoretical and practical problems which might result from the CJPOA. In particular, inadequate consideration was given to the effect that allowing inferences to be drawn from no-comment interviews at the police station would have on the protective value of custodial legal advice, and the relationship between suspects and their legal representatives. ${ }^{18}$

This article argues that suspects have been trebly disadvantaged by the CJPOA. The right of silence has been diminished, legal representation has been devalued, and the encroachment on such 'a "bench mark" of British justice'19 facilitated further statutory and common law restrictions on evidential protections for defendants. The argument is primarily based on the case-law and literature but it also draws illustrative quotes from the findings of a qualitative study conducted in the early days of the CJPOA. ${ }^{20}$ Part one explains how the CJPOA was based upon the false premise that prosecutions and convictions were being thwarted by legal advisers advising their guilty clients to make nocomment interviews. Such criticisms were expressed at the time, but are summarised here in order to illustrate the full trajectory of the changes and the unfair foundations of the process. Part two examines how a largely unsympathetic Court of Appeal has developed the scope of the provisions in accordance with the exchange-abolitionist viewpoint and by ignoring the practical difficulties faced by legal representatives at the police station. It is argued that this has compromised the lawyer-client relationship - beyond Cape's suggestion of defence lawyers being merely 'sidelined'21 - and undermined legal representatives' ability

13 The only published empirical study to date is T Bucke, R Street and D Brown, The Right of Silence: The Impact of the Criminal Justice and Public Order Act 1994 (Home Office Research Study 1999, Home Office 2000).

$14 \mathrm{Cl} 11$ of the Liberal Democrats' draft Freedom Bill 2009 which proposed the 'repeal of provisions which restrict the right to silence' attracted little attention (the document has been removed from the Liberal Democrats' website; a copy is on file with the author). The government decided not to include it in the Protection of Freedoms Bill 2010-2011 because the current arrangements 'strike the right balance' (email correspondence between the author and the Ministry of Justice, dated 1 August 2011).

15 I Dennis, 'Silence in the Police Station: the Marginalisation of Section 34' [2002] Crim LR 25-38.

16 D Birch, 'Suffering in Silence: A Cost-Benefit Analysis of Section 34 of the Criminal Justice and Public Order Act 1994' [1999] Crim LR 769-88.

17 R Leng, 'The Right to Silence Reformed: A Re-appraisal of the Royal Commission's Influence' (2001) 6(2) Journal of Civil Liberties 107-33, 125.

18 Legal representation at the police station must be provided by either a solicitor who holds a current practising certificate, or an accredited or probationary representative included on the register of representatives maintained by the Legal Services Commission (para 6.12 Code C PACE). The terms 'solicitor' 'lawyer' and 'legal representative' are used interchangeably in this article but not all those acting at the police station are fully qualified.

19 J D Jackson, 'Curtailing the Right of Silence: Lessons from Northern Ireland' [1991] Crim LR 404-15, 415.

20100 semi-structured interviews were conducted with criminal justice practitioners from five differently sized locations in one large metropolitan region of England between 1998 and 2001 (legal representatives, barristers, crown prosecutors, magistrates, legal advisers and judges). Each lasted around one hour and was fully transcribed and coded. An additional 100 questionnaires were completed by police officers (out of 300 issued).

21 E Cape, 'Sidelining Defence Lawyers: Police Station Advice after Condron' (1997) 1 E\&P 386-402. 
to protect their clients at the police station. The CJPOA has created an expectation that the accused will co-operate with proceedings against them, in many cases making it easier for the prosecution to discharge the burden of proof. Jackson's argument that the CJPOA provisions have effectively made the police interview part of the trial process ${ }^{22}$ is expanded upon to suggest that the provisions have imported to the courtroom traditional police suspicion of defendants and their legal representatives. Part three of the article explores how, in accordance with this viewpoint, the courts have interpreted the CJPOA provisions to the detriment of another 'fundamental condition', that of legal professional privilege. Despite the apparent acceptance of the status quo, it is this 'ripple effect' of the legislation that calls for further examination of the issue. Leng argues that the focus on implementing the law 'must not obscure the extent to which the current law compromises the core notions of adversarial justice and fair trial'. ${ }^{23}$ When considered holistically, it is argued that the cumulative effects of the legislation have been corrosive to many aspects of the adversarial process but, in particular, and the focus of this article, on the right to legal representation at the police station.

\section{Exchange abolitionism: part one of a three-card trick}

Opposition to the right of silence is not new; Jeremy Bentham's criticism of it as the first law a team of criminals would draft are cited routinely by abolitionists. ${ }^{24}$ Legislation to curtail the right of silence was drafted by the Criminal Law Revision Committee in $1972^{25}$ but was shelved following formidable opposition. ${ }^{26}$ The next major review of the system by the 1981 Royal Commission on Criminal Procedure carefully balanced increased powers for the police against improved protections for suspects and explicitly included the right of silence as part of that equation. ${ }^{27}$ Its recommendations were largely given effect by PACE which provides miscellaneous requirements to ensure minimum standards of detention, that interviews are conducted properly and are tape-recorded. Of particular significance for this debate, suspects must be informed that they have the right to free, independent legal advice, in private, by telephone, in writing or in person, which may be delayed only in exceptional, limited circumstances. ${ }^{28}$ The function of the legal representative is solely 'to protect and advance the legal rights of his client'; this includes explaining, and sometimes advising, the exercise of the right of silence. ${ }^{29}$

The post-PACE regime was portrayed by some politicians as assisting 'professional criminals, hardened criminals and terrorists who disproportionately take advantage of and

22 J Jackson, 'Silence Legislation in Northern Ireland: The Impact after Ten Years' (2001) 6(2) Journal of Civil Liberties 134-49.

23 Leng (n 17) 133.

24 Cross (n 1) 73; Criminal Law Revision Committee, Eleventh Report: Evidence (General) (Cmnd 4991, 1972) 18; G Williams, 'The Tactic of Silence' (1987) 137 NLJ 1107; P Imbert, 'Policing London' (1988) 61 Police Journal 199, 203; I McKenzie and B Irving, 'The Right of Silence' (1988) 4 Policing 88, 91-92; Michael Bates MP HC Deb 7 July 1993, vol 228, col 334.

25 Criminal Law Revision Committee (n 24).

26 M Zander, ‘The CLRC Report: A Survey of Reactions' (1974) LSG (7 October); P Evans, 'Criminal Law Revision Proposals Received with Heavy Criticism’ The Times (28 June 1972) 1.

27 Royal Commission on Criminal Procedure, Report (Cmnd 8092, 1981).

28 See Code of Practice C, Annex B. A less favourable regime is in place for suspects detained under s 41 Terrorism Act 2000; this is governed by Code H.

29 PACE Code C, 6D. 
abuse the present system, 30 and the police 'waged a concerted campaign'31 to this effect. Following PACE, the Court of Appeal was generally supportive of legal representation ('in marked contrast to the pre-1984 attitude'), ${ }^{32}$ but appeared to regard this as coming at a price. First, it took the view that the presence of a legal representative put suspects on 'equal' or 'even' terms with the police, ${ }^{33}$ meaning that improperly obtained evidence need not always be excluded. It then went further in aiming 'to secure a quid pro quo for the enforcement of section 58 rights [to legal advice], in terms of a new right to comment adversely on a suspect's failure to reveal a defence later sprung on the prosecution'. ${ }^{34}$ Some senior judges and prosecutors also expressed this view in a personal capacity. 35

In 1988, a Home Office Working Group ${ }^{36}$ was established to report how, rather than whether or not, the right of silence should be curtailed. The right was 'removed with unseemly despatch'37 in Northern Ireland, ostensibly following a number of terrorist incidents. ${ }^{38}$ Following a series of terrorism-related miscarriages of justice, reforms were deferred in England and Wales until the Royal Commission on Criminal Justice (RCCJ) ${ }^{39}$ was controversially asked to consider the question once again. The majority of the RCCJ concluded that:

the possibility of an increase in the convictions of the guilty is outweighed by the risk that the extra pressure on subjects to talk in the police station and the adverse inferences invited if they do not may result in more convictions of the innocent. 40

The government rejected the advice of the RCCJ and introduced the CJPOA, beginning an era of criminal justice policy based on the premise that: 'The balance in the criminal justice system is tilted too far in favour of the criminal and against protecting the public. ${ }^{31}$ Such a policy appeared politically driven ${ }^{42}$ rather than evidentially based. It is thus perhaps unsurprising that the legislation had unforeseen consequences. Dennis found that 'none of the claims which have driven the reform of the right to silence have any very secure

30 Michael Howard, HC Deb 11 January 1994, vol 235, col 26. The Secretary of State for Northern Ireland had commented similarly when curtailing the right of silence in Northern Ireland a few years earlier (Tom King, HC Deb 8 November 1988, vol 140, col 184).

31 J Jackson, 'Silence and Proof: Extending the Boundaries of Criminal Proceedings in the United Kingdom' (2001) 5 E\&P 145-73, 145.

32 A A S Zuckerman, The Principles of Criminal Evidence (Clarendon Press 1989) 340.

33 R v Chandler [1976] 3 All ER 105, 110; R v Smith (1985) 81 Cr App R 286, 292.

34 D Birch, 'Case Comment, Confession: Denial of Access to a Solicitor' [1988] Crim LR 449-52, 452. See also Zuckerman (n 32) 327 and cases such as R v Alladice (1988) 87 Cr App R 380, 385; R v Gilbert (1978) 66 Cr App R 237.

35 Lord Denning, 'Free Justice from Silence' The Sunday Times (20 September 1987); Lord Chief Justice Taylor, HL Deb 23 May 1994, vol 555, col 519; and the 'Tom Sergant Memorial Lecture' (1994) 144 NLJ 125.

36 HC Deb 18 May 1988, vol 133, cols 465-66W; Home Office, Report of the Working Group on the Right to Silence (HMSO 1989).

37 Greer (n 12) 710.

38 Criminal Evidence (Northern Ireland) Order 1988 SI 1988/1987. See J Jackson, 'Recent Developments in Criminal Evidence' (1989) 40 NILQ 105-30.

39 RCCJ, Report (Cm 2263, 1993). See point (v) of its terms of reference.

40 Ibid 54.

41 Michael Howard, HC Deb 11 January 1994, vol 235, col 25.

42 Birch suggests that it is likely that section 34 owes its existence not so much to a considered choice between opposing views, as to the political incentive to reflect a change already made in Northern Ireland' (n 16) 772 (footnote omitted). It was also part of a change in policy set out in Michael Howard's 27-point plan announced to the Conservative Party Conference in October 1993. 
foundation'. ${ }^{43}$ Empirical evidence was available at the time that showed the right of silence was not exercised widely and was not insurmountable in achieving convictions. ${ }^{44}$ Brown $^{45}$ reviewed the research to produce a 'best estimate' of the extent of the exercise of the right. He found that 5 per cent of suspects remained completely silent to police questions and between 6 per cent and 10 per cent remained partially silent. Leng's report for the RCCJ found no evidence that the right of silence was impeding prosecutions, or that no-comment interviews led to ambush defences at court. ${ }^{46}$

The exchange-abolitionist view of legal representation also favoured instinct over evidence. The right to legal advice at the police station has been described as an essential feature of a fair trial. ${ }^{47}$ Article 6(3)(c) of the European Convention on Human Rights (ECHR) states that everyone charged with a criminal offence has the right 'to defend himself in person or through legal assistance of his own choosing or, if he has not sufficient means to pay for legal assistance, to be given it free when the interests of justice so require'. Research available at the time showed that less than one-third of suspects ${ }^{48}$ was legally represented at the police station, that there was a 'lack of expertise and experience 49 amongst many representatives, and that legal advisers were rarely as combative as they were claimed to be by the sponsors of the Act. ${ }^{50}$ Many legal advisers regarded themselves as neutral referees or 'babysitters' 51 and did not want to risk prejudicing their working relationship with the police by advising no-comment interviews. ${ }^{52}$ As one said:

You've got to be lenient with the police, if you start rocking the boat with the police, then when you want some co-operation, you might not get it and at the end of the day, we're all there for the same thing aren't we - one side or the other side?53

The protections offered by PACE were undoubtedly an improvement on the common law, and the accreditation scheme for police station legal advisors has improved standards. ${ }^{54}$ Suspects cannot be on 'even terms' with the police, however, when officers do not have to make full disclosure of their case, nor can a solicitor ameliorate the psychological effects of

43 I Dennis, 'The Criminal Justice and Public Order Act 1994: The Evidence Provisions' [1995] Crim LR 4-18, 14.

$44 \mathrm{R}$ Leng, The Right to Silence in Police Interrogation: A Study of Some of the Issues Underlying the Debate (Royal Commission on Criminal Justice Research Study No 10, HMSO 1993); M McConville and J Hodgson, Custodial Legal Advice and the Right to Silence (HMSO 1993).

45 D Brown, 'The Incidence of Right of Silence in Police Interviews: The Research Evidence Reviewed' in Research Bulletin No 35 (Home Office Research and Statistics Department 1994) 57-75.

46 Leng (n 44).

47 Murray (John) v UK (1996) 22 EHRR 29; Salduz v Turkey (2008) 49 EHRR 421; Cadder (Peter) v HM Advocate [2010] UKSC 43.

48 D Brown, T Ellis and K Larcombe, Changing the Code: Police Detention under the Revised PACE Codes of Practice (Home Office Research Study No 129, Home Office, 1992).

49 J Hodgson, 'Tipping the Scales of Justice: The Suspect's Right to Legal Advice' [1992] Crim LR 854-62, 861; D Dixon, A K Bottomley, C A Coleman, M Gill and D Wall, 'Safeguarding the Rights of Suspects in Police Custody' (1990) 1 Policing and Society 115-40; M McConville, J Hodgson, L Bridges and A Pavlovic, Standing Accused: The Organisation and Practices of Criminal Defence Lanyers in Britain (Oxford University Press 1994) 41; D Brown, PACE Ten Years On: A Review of the Research (Home Office Research Study No 155, HMSO1997).

50 J Baldwin, The Role of Legal Representatives at the Police Station (RCCJ Research Study No 3, HMSO 1993); McConville et al (n 49).

51 Solicitor/B2/i; J Hodgson, 'Adding Injury to Injustice: The Suspect at the Police Station' (1994) 21 Journal of Law and Society 85-101, 94; J Baldwin, 'Legal Advice in the Police Station' (1992) NLJ 1762-64, 1764.

52 McConville and Hodgson ( $\mathrm{n} 44) 89$.

53 Legal Executive (P)/F7/i); see also D Dixon, 'Common Sense, Legal Advice and the Right of Silence' (1991) PL 233-54, 246.

54 L Bridges and S Choongh, Improving Police Station Legal Advice (Law Society and Legal Aid Board 1998). 
detention. ${ }^{55}$ Although the police seem more comfortable with the presence of legal advisers nowadays, interviews take place on their territory and, to an extent, on their terms..$^{56}$ Research published before the CJPOA was enacted showed that the police were using 'tactics, or ploys ${ }^{57}$ to mitigate or minimise the effects of PACE. Officers have a wide discretion in the exercise of their powers, whereas legal representatives have little authority to enforce police compliance with the rules. The refusal to answer questions was hitherto the main bargaining chip that suspects and legal advisers possessed in response to the police exploiting, exceeding or abusing their powers. ${ }^{58}$

The CJPOA was based on the extraordinary syllogism that, if legal advisers were recommending that suspects exercise their rights, or were inhibiting the police from infringing these rights, then one of the most symbolic protections for suspects should be curtailed in order to 'rebalance' the system. There was no evidential basis for these claims, but much to contradict them. Whilst the Act was ostensibly targeted at the undeserving who were 'exploiting' the protections introduced to protect the vulnerable, its provisions apply to all, whether or not they have legal representation, and it is noteworthy that still fewer than half of suspects do. ${ }^{59}$

This unfair exchange has not settled the 'balance' between suspect and the police; the CJPOA appears rather to have marked the legislative start of 'the modern law and order arms race'. ${ }^{60}$ Leng has argued that the CJPOA 'represents a re-negotiation of the relationship between citizen and state. ${ }^{61}$ Cape considers that '[a]ttempts to circumscribe the newly invigorated role of defence lawyers' were not limited to the CJPOA provisions but 'whether as a result of design or consequence' 62 may be discerned in other Acts. Further legislation has been passed encroaching on due process protections to an extent that would previously have been thought impossible, such as the creation of pre-trial disclosure obligations for the defence; exceptions to the double jeopardy rule; and the admission of bad character and hearsay evidence. ${ }^{63}$ The CJPOA appears to have facilitated some of this; opposition to the disclosure requirements was rebutted on the basis that defence disclosure required little more of defendants than the CJPOA. As Belloni and Hodgson have noted, 'the availability of legal advice continues to be weighed in the scales by the courts, police and policy-makers to justify further encroachment upon the suspect's position'. ${ }^{64}$ The next section considers the role of the courts in this attritional process.

55 S Easton, 'Legal Advice, Common Sense and the Right to Silence' (1998) 2(2) E\&P 109-22, 119-20.

56 McConville et al (n 49) 131.

57 A Sanders, L Bridges, A Mulvaney and G Crozier, Advice and Assistance at Police Stations under the 24-hour Duty Solicitor Scheme (Lord Chancellor's Department 1989) 56.

58 Dixon (n 53) 246.

59 In the largest recent survey, $45 \%$ of suspects requested legal advice, with $36.5 \%$ actually receiving a consultation: P Pleasence, V Kemp and N J Balmer, 'The Justice Lottery? Police Station Advice 25 Years on From PACE' [2011] Crim LR 3-18. See also L Skinns, who found a $60 \%$ request rate, with $48 \%$ resulting in a consultation ("I'm a Detainee; Get Me Out of Here": Predictors of Access to Custodial Legal Advice in Public and Privatized Police Custody Areas in England and Wales' (2009) 49(3) British Journal of Criminology 399-417.

60 S Chakrabarti, 'A Thinning Blue Line? Police Independence and the Rule of Law' (2008) 2(3) Policing 367-74, 369.

61 Leng (n 17) 132.

62 E Cape, 'The Rise (and Fall?) of a Criminal Defence Profession' [2004] Crim LR 50th Anniversary Edition $72-87,85$.

63 Pt II Criminal Procedure and Investigations Act 1996; Criminal Justice Act 2003. Cape adds to this list the limiting of the appeal rights of terrorist suspects by the Anti-Terrorism, Crime and Security Act 2001, the taking of fingerprints, photographs and samples, and some of the amendments to PACE in the Criminal Justice Act 2003 (n 62).

64 F Belloni and J Hodgson, Criminal Injustice: An Evaluation of the Criminal Justice Process in Britain (Macmillan 2000) 43. 


\section{The widening scope of the CJPOA: the Court of Appeal raises the stakes}

The CJPOA gave no guidance as to what a proper inference from silence might be but the case-law has developed a presumption that any inference drawn will be adverse. ${ }^{65}$ Whilst there have been ebbs and flows in its approach, overall the Court of Appeal has developed the provisions enthusiastically, as happened in both Singapore and Northern Ireland when similar changes were introduced in those jurisdictions. ${ }^{66}$ Leng argues that, in its interpretation of s 34, the Court has 'signalled its allegiance to the political objective of the legislation: to establish the norm that suspects should speak in police interview'. ${ }^{67}$ The Court now considers 'the police interview and the trial are to be seen as part of a continuous process in which the suspect is engaged from the beginning . . . [a] benign continum from interview to trial'. ${ }^{68}$ Whilst directions are given to the jury in each case about the presumption of innocence and the burden of proof, 'to permit the adverse inference must alleviate the prosecution's burden to some degree'. ${ }^{69}$

The Court has made clear that juries should scrutinise both solicitors' reasons for recommending no-comment interviews and suspects' motivations for accepting that advice; in effect, such conduct now has to be justified. Little attention has been given to the effect of these decisions on the ability of defence solicitors to perform their primary function of protecting their clients, and also of ensuring that the police do not exceed their powers. As illustrated below, the judgments are insufficiently consistent for legal representatives to have confidence that advising no-comment interviews will not prejudice their clients should their cases proceed to trial. This section examines the Court's approach to the CJPOA, in particular regarding silence on legal advice, and the impact this has had on legal representatives' ability to fulfil their role.

\subsection{The COURT'S APPROACH TO ADVERSE INFERENCES AND LEGAL ADVICE}

The Crown Court Bench Book, a reference source for judges preparing summings-up for juries, explains that 'the object of section 34 is to deter late fabrication of defences and to encourage early disclosure of genuine defences'. ${ }^{70}$ The jury must be directed that it may only draw an inference, if, apart from the defendant's failure to mention facts later relied on in his or her defence, the prosecution case is so strong that it clearly calls for an answer. It must also be satisfied that there is no sensible explanation for the defendant's failure, other than that he or she had no answer at that time or none that would stand up to scrutiny. The jury must be told that an inference should be drawn only if they think it is fair and proper to draw such a conclusion. A defendant must not be convicted wholly or mainly on the strength of the inference. ${ }^{71}$ Despite having held previously that the provisions 'should not be construed more widely that the statutory language requires', ${ }^{72}$ the Court appears to have gone beyond this. The adverse inference is no longer limited to one of recent invention, but

$65 \mathrm{R} v$ Condron and Condron [1997] 1 WLR 827; R v Napper [1996] Crim LR 591.

66 M Yeo, 'Diminishing the Right to Silence: The Singapore Experience' [1983] Crim LR 88; J Jackson, M Wolfe and K Quinn, Legislating against Silence: The Northern Ireland Experience (Northern Ireland Statistics and Research Agency 2000).

67 R Leng, 'Silence Pre-trial, Reasonable Expectations and the Normative Distortion of Fact Finding' 5(4) E\&P (2001) 240-56, 249-50.

68 R v Howell [2003] EWCA Crim 1; 1 Cr App R 1 [23]-[24].

69 D Hamer, 'The Privilege of Silence and the Persistent Risk of Self-incrimination: Part 1' (2004) 28 Crim LJ $160-78,161$.

70 Crown Court Bench Book <www.judiciary.gov.uk>, 258.

71 Ibid.

$72 \mathrm{R} v$ Bowden [1999] 1 WLR 823, 827. 
now extends to a fact or explanation tailored to fit the prosecution case or which the defendant is thought to have believed would not stand up to scrutiny at the time. ${ }^{73}$ When directing jurors how to treat evidence of a no-comment interview, judges should substitute 'conclusions' for 'inferences', ${ }^{74}$ which appears to give the 'evidence' greater weight.

The Court has been reluctant to create exclusions to the provisions, preferring to leave the issue to the jury, buttressed by lengthy directions. ${ }^{75}$ Redmayne suggests that the 'directions operate rather like a magic formula; so long as they are given by the judge, the jury can be left to draw an inference. The European Court of Human Rights (ECtHR) has taken a similar approach. ${ }^{, 76}$ The idea that remaining silent on legal advice would protect defendants from adverse inferences ${ }^{77}$ was summarily dismissed in the first 'silence' case to reach the Court of Appeal. The Court considered that this 'would render section 34 wholly nugatory 78 as any competent solicitor would then be bound to advise silence. As with the legislation itself, this 'policy driven'79 decision ignored how few no-comment interviews there actually were before the law changed, but it resonated with the broader political rhetoric about hardened criminals, abetted by their overly adversarial lawyers, abusing their rights. The jury should be told: 'It is not what the solicitors thought that matters. It is what each defendant thought. ${ }^{\text {}} 8$ This ignores the fundamental premise of s 58 PACE, which is that the professional offers expert advice to the lay client or, as one defendant retorted, 'Well, what was the point of me having a solicitor there, if I wasn't going to actually take his advice?'81 The Court explained that it will assume that solicitors will have given proper advice and this must include an explanation of s 34 and the risks of withholding facts from the police. 'It is with the benefit of that advice that an appellant himself makes the decision whether to answer questions or whether to decline to do so and take the risk which goes with it.' ${ }^{82}$ The directions fail to consider the generally dismal levels of educational attainment amongst those in custody; the number for whom English is not their first language; the incidence of mental illness; and the extent of drug and alcohol abuse amongst suspects. ${ }^{83}$ The ECtHR made little criticism of the provisions but held that the fact that an accused has remained silent on legal advice must be given 'appropriate weight' by the Court, adding that it is essential to a fair trial for the judge to direct the jury not to draw an inference if they are

73 R v Milford [2001] Crim LR 330; although in the context of prepared statements, the Court held that the objective of the provisions is early disclosure of a suspect's account and not, separately and distinctly, its subjection to police cross-examination ( $\mathrm{R} v$ Knight [2004] 1 Cr App R 9, CA; R v Turner (Dwaine) [2004] 1 Cr App R 24, CA).

74 Crown Court Bench Book ( n 70) app 2.

75 See the concerns expressed in R v Bresa [2005] EWCA Crim 1414, [4]-[5].

76 M Redmayne, 'English Warnings' (2008) 30(3) Cardozo Law Review 1047-88, 1060.

77 RCCJ (n 39) 54; The Law Society's guidelines at the time suggested 'non-tactical' motives would not attract inferences. Home Secretary Michael Howard had, however, stated that this was not his intention as the Bill was debated in Parliament (HC Deb 11 January 1994, vol 235, col 26).

78 Condron (n 65) 833.

79 Leng (n 17) 127.

80 R v Betts; R v Hall [2001] 2 Cr App R 257, 271.

81 Howell (n 68) [6]; Zuckerman (n 32) 30, raised this problem before the CJPOA, referring to judgments from the USA that found such silence to be 'insolubly ambiguous' because it could not be known whether it was due to a sense of guilt, or a preference to exercise the constitutional privilege (Doyle v Obio 426 US 610 (1976) also US $v$ Hale 422 US 171 (1975)).

82 Essa (n 5) [15].

83 See J J Payne-James, P G Green, N Green, G M C McLachland, M H W M Munro and T C B Moore, 'Healthcare Issues of Detainees in Police Custody in London, UK' (2010) 17(1) Journal of Forensic and Legal Medicine 11-170. 
satisfied that the defendant remained silent on legal advice. ${ }^{84}$ The domestic courts have had some difficulty in giving effect to [this] ruling, ${ }^{85}$ The Court of Appeal appears to have found the crime control ${ }^{86}$ arguments more compelling than those of human rights in relation to the right of silence. The Court first held that it is not the quality of the suspect's decision to remain silent that matters but the genuineness of that decision; 87 it then held that the jury should apply a more stringent objective ${ }^{88}$ test in deciding this. To date its parsing of the judgment in this way has not been challenged in Strasbourg.

The Court of Appeal has taken an increasingly elastic view as to when the police are allowed to question a suspect against whom they have sufficient evidence to charge. Section 37(2) of PACE requires custody officers to charge or release a suspect if they determine that they have sufficient evidence to charge them. Initially it was held that inferences should not be drawn in cases where the interviewing officer believed, prior to an interview, that there was sufficient evidence for a successful prosecution. ${ }^{89}$ The Court then resiled from this, holding that decisions about prosecution must involve consideration of any explanation given by the suspect. ${ }^{90}$ In the 'pushmi-pullyu' way in which government and the judiciary have dealt with these cases, the PACE Codes of Practice were then revised to give effect to this. This gives greater scope to the interviewing officer to continue questioning and in a manner which is difficult to reconcile with s $37(2) .{ }^{91}$

The Court reinforced its commitment to establishing the norm of suspects answering questions in Hoare:

It is not the purpose of section 34 of the 1994 Act to exclude a jury from drawing an adverse inference against a defendant because he genuinely or reasonably believes that, regardless of his guilt or innocence, he is entitled to take advantage of that advice to impede the prosecution case against him. In such a case the advice is not truly the reason for not mentioning the facts . . Legal entitlement is one thing. An accused's reason for exercising it is another. ${ }^{92}$

It is unclear how it can be 'unreasonable' for a suspect to follow legal advice, other than by the implication that it is being used as a pretext to evade conviction. As for discerning the true explanation, this is an entirely speculative exercise, as the jury cannot know the defendant's reasoning; there may not even be a 'true' explanation. Despite the caveat about innocence, the Court's reasoning makes sense only if the defendant is guilty. A factually innocent suspect may be affronted at being arrested and refuse to answer police questions in protest; this would truly be the reason for remaining silent but not one for which the Court allows in the above judgment. Although jurors must be directed not to convict the defendant wholly or mainly on the strength of the inference, if they decide the inference is

84 Condron v UK (2001) 31 EHHR 1, [60]-[62].

85 Lord Phillips of Worth Matravers, 'Trusting the Jury' (Criminal Bar Association Kalisher Lecture 2007) <www.judiciary.gov.uk/Resources/JCO/Documents/Speeches/lcj_trusting_juries_231007.pdf> 6 accessed 27 June 2013.

86 R Pattenden, 'Silence: Lord Taylor's Legacy’ (1998) 2(3) E\&P 141-65, 164.

87 Betts and Hall (n 80) 270.

88 R v Hoare and Pierce [2005] 1 WLR 1804; [2004] EWCA Crim 784, following Howell (n 68); and R v Knight [2003] EWCA Crim 1977, rather than the subjective test preferred in Betts and Hall (n 80).

89 Para 11.4 of the old Code C (see E Cape, 'Detention without Charge: What Does "Sufficient Evidence to Charge” Mean?” [1999] Crim LR 87); R v Pointer [1997] Crim LR 676; and R v Gayle [1999] Crim LR 502.

90 R v McGuinness [1999] Crim LR 318; R v Ioannou [1999] Crim LR 586; R v Elliott [2002] EWCA Crim 931; Howell (n 68).

91 Para 11.6 of the new Code C. See E Cape 'The Revised PACE Codes of Practice: A Further Step Towards Inquisitorialism' [2003] Crim LR 355-69.

92 Hoare and Pierce (n 88) [54]; see also Howell (n 68) [23]-[24]. 
adverse, this now seems likely to be decisive. A jury might accept that a suspect remained silent on legal advice, yet convict upon other evidence; it is unlikely to assume a suspect accepted the lawyer's advice because he or she was guilty and then acquit. ${ }^{93}$ This has worrying consequences for the value of legal advice:

The value of legal advice is thus diminished. If defendants can never be sure that they are acting reasonably in relying on the advice of their lawyer, then they can never be sure that they should accept their lawyer's advice. If they cannot be sure about that, then it raises the fundamental question of the utility of legal advice at the police station. Custodial legal advice may be guaranteed by the European Convention on Human Rights, but its value as such is in danger of being seriously eroded. ${ }^{94}$

\subsection{The IMPLICATIONS FOR LEGAL REPRESENTATIVES}

As well as making it more difficult for the accused to follow the advice of their lawyers, the judgments of the courts in these cases have made it much harder for legal representatives to decide how best to advise their clients. The Court of Appeal has stated that the kind of circumstance which may justify $y^{95}$ a solicitor advising silence (an interesting choice of words) will be matters such as the suspect's condition (ill-health, in particular mental disability; confusion, intoxication or shock), or genuine inability to recollect events without reference to documents, or communicating with others. In deciding what is reasonable, a court is to consider the particular accused with such qualities, knowledge, apprehensions and advice as he or she was shown to have had at the time. ${ }^{96}$ This has been interpreted inconsistently, however. The Court rejected the decision of the Condrons' solicitor that, contrary to the view of the police doctor, they were unfit to be interviewed, due to the effects of heroin withdrawal. ${ }^{97}$ It is difficult to conceive of a situation in which it would be more reasonable for a suspect to follow the advice of his representative than where, as in Roble, ${ }^{98}$ the solicitor considered his understanding of English to be insufficient to deal with difficult legal concepts and she was unclear what his instructions were. The Court of Appeal disagreed, however; as the solicitor did not give evidence of all the facts her client had told her, it did not know the basis upon which she had formulated her advice. To follow the judges' own reasoning, if they are not considering the correctness of the solicitor's advice, they do not need to know the logic underpinning it. ${ }^{99}$ Such analysis demonstrates further the scepticism of the courts to those making no comment. Reasons for the legal representative's advice are deemed irrelevant when they are adduced to avoid inferences or to support excluding the interview (it is the defendant's reasons for silence that are significant) but the legal representative's lack of reasons may be used as justification for drawing inferences.

The Court refused from the outset to exclude no-comment interviews where the legal advice was tactically based, on the grounds that the advice may not be bona fide; there may be more than one reason for giving it; and 'it is not so much the advice given by the solicitor, as the reason why the defendant chose not to answer questions that is important and this is

93 What Wolchover describes as 'classic petition principia - assuming what is to be proved as an essential component of the would-be proof': D Wolchover, 'Serving and Saving Silent Suspects: Part 2' (12 February 2011) 175 Criminal Law and Justice Weekly 86-88, 88.

94 Cape (n 21) 402.

95 Howell (n 68) [24].

$96 \mathrm{R} v$ Argent [1997] 2 Cr App R 27.

97 Condron (n 65).

$98 \mathrm{R} v$ Roble [1997] Crim LR 449.

99 See Cape (n 21) 402. 
a question of fact which may be very much in issue'. ${ }^{100}$ The 'acid question' in these cases is not was it reasonable to rely on the solicitor's advice, but rather, could the appellant reasonably have been expected to say what is then relied upon at trial? ${ }^{101}$ The Court went on to give examples of what would not be considered reasonable grounds for making no comment: the absence of a written statement from the complainant; the likelihood that the complainant will withdraw; or the solicitor's belief that the suspect will be charged anyway. ${ }^{102}$ These are all 'tactical' reasons that would give practical effect to the principle that the burden of proof lies on the prosecution. These judgments suggest a worryingly instrumental view that infringing suspects' rights matters less than gaining a confession if it convicts the guilty - a viewpoint which PACE had had an significant role in changing - and assumes that little harm will come to the innocent who should be willing to submit to the indignity of an illegal interview in order to exculpate themselves. The Court has reaffirmed this view of the primacy of co-operation, leaving inferences to the jury in a case in which silence was advised due to the expiration of the lawful detention period for one suspect and it was not clear that the police had evidence to suggest that the other had committed an offence. ${ }^{103}$

The extraordinary judgment in Howell shows how far the Court has adopted the crimecontrol rhetoric that infused the CJPOA. It makes clear that, regardless of the presumption of innocence, suspects are expected to co-operate with proceedings against themselves and has extended the effect of the Act much further than had ever been anticipated.

... if currency is given to the belief that if a suspect remains silent on legal advice he may systematically avoid adverse comment at his trial. And it may encourage solicitors to advise silence for other than good objective reasons ... There must always be soundly based objective reasons for silence, sufficiently cogent and telling to weigh in the balance against the clear public interest in an account being given by the suspect to the police. Solicitors bearing the important responsibility of giving advice to suspects at police stations must always have this in mind. ${ }^{104}$

This is a fundamental change in the nature of the role of the legal adviser for which there is no legislative authority; in fact the PACE Codes appear to contradict this directly:

The solicitor's only role in the police station is to protect and advance the legal rights of their client. On occasions this may require the solicitor to give advice which has the effect of the client avoiding giving evidence which strengthens a prosecution case. The solicitor may intervene in order to seek clarification, challenge an improper question to their client or the manner in which it is put, advise their client not to reply to particular questions, or if they wish to give their client further legal advice. ${ }^{105}$

Defence solicitors now face a conflict between their statutory and professional obligations, ${ }^{106}$ to advise and to act in their clients' best interests, and the changed approach of the Court. This impasse appears impossible to resolve in their clients' favour whilst the Court maintains its current stance.

100 Condron (n 65) 833.

101 Essa (n 5) [15].

102 Howell (n 68) [24].

103 Hoare and Pierce (n 88) [3].

104 Howell (n 68) [23]-[24], emphasis added.

105 PACE Code C, para 6D, emphasis added.

106 'Advice to Practitioners from the Criminal Law Committee of the Law Society', Criminal Practitioners Newsletter (October 1994); 'Law Society Advice to Practitioners', Criminal Practitioners Newsletter (July 1997); 'Changes in the Law Relating to Silence', Criminal Practitioners Newsletter (January 2006). 
Cape notes the 'signs of a growing antipathy towards adversarial principles and the adversarial role of defence lawyers'. ${ }^{107}$ It has been suggested, both in the Court of Appeal and ECtHR, that a good reason for not drawing an adverse inference would be 'bona fide advice received from his lawyer'. 108 This is a troubling term as it suggests by implication that lawyers may advise in bad faith and, following the logic of the case-law described above, this could include advising suspects to make no comment for tactical reasons. Such a view assumes the public interest inheres only in achieving convictions, rather than in cases being investigated and tried in an appropriate manner. The term was used in Averill v UK, ${ }^{109}$ a case that related to the analogous provisions operating in Northern Ireland at a time when 'the security forces in Northern Ireland violate[d] basic international standards safeguarding the role of lawyers on a regular basis' ${ }^{110}$ Defence solicitors are officers of the court ${ }^{111}$ and, in the absence of evidence to the contrary, should be presumed to be acting in good faith. Lawyers 'should never be identified with their clients or their clients' causes as a result of discharging their functions'. ${ }^{112}$

The old legal aphorism of 'if in doubt, say nowt [nothing]', whilst never satisfactory, or as widespread as the police believed, became positively negligent after April 1995. Legal representatives have to make decisions quickly and in difficult circumstances, often in ignorance of some or all of the facts, knowing that their decision could have negative repercussions for their clients:

The imposition on the lawyer is really quite tough, because we are now in a very unenviable position of, if our advice is wrong and we don't give adequate legal protection to our client ... it's an element that can be used to convict them . . . There is more thought process required. ${ }^{113}$

At 3 o'clock in the morning you've been dragged out of bed, your pyjamas are sticking out from underneath your jeans and you're trying to write a cogent note about why you've given certain advice which somebody is going to sniff over nine months later. ${ }^{114}$

Poor legal advice is not, of itself, a ground of appeal, rather the appellant has to show that the incompetence led to identifiable errors or irregularities in the trial, which themselves rendered the process unfair or unsafe. ${ }^{115}$ If the Court of Appeal tends to the view that solicitors should advise their clients to answer questions, it seems unlikely that it will sympathise with an appellant who claims to have been ill advised to answer questions. If it

107 Cape (n 62) 85-86. He cites Gleeson [2003] EWCA Crim 3537 and Hughes v DPP [2003] EWHC 2470 (Admin). See also R (on the application of the DPP) $v$ Chorley Justices [2006] EWHC 1795; Arthur JS Hall and Cov Simons (AP) [2000] UKHL 38, [2002] 1 AC 615).

108 Averill v UK (2001) 31 EHRR 36, [47]; Condron (n 65) 833.

109 Averill v UK (2001) 31 EHRR 36, [47].

110 Lawyers Committee for Human Rights, Human Rights and Legal Defense in Northern Ireland: The Intimidation of Defense Lawyers and the Murder of Patrick Finucane (Lawyers Committee for Human Rights 1993) 25. See also: Sir J Stevens, Overview and Recommendations, 17 April 2003 (PSNI 2003); U Lucy, 'Improper Inference: The Perils of Defending Suspected Terrorists in Northern Ireland' (2003) 15(2) Pace International Law Review 411-36; K McEvoy, 'What Did the Lawyers Do During the "War"? Neutrality, Conflict and the Culture of Quietism' (2011) 74 MLR 350-84.

111 See Solicitors' Regulation Authority, Code of Conduct (2011) <www.sra.org.uk/solicitors/handbook/ code/content.page $>$ accessed 27 June 2013.

112 Principle 18 of United Nations, Basic Principles on the Role of Lanyers, 7 September 1990 <www.unhcr.org/ refworld/docid/3ddb9f034.html> accessed 27 June 2013.

113 Legal Executive B1/ii.

114 Solicitor D9/ii.

115 R v Day [2003] EWCA Crim 1060. See E Cape 'Incompetent Police Station Advice and the Exclusion of Evidence' [2002] Crim LR 471-84. 
takes the view that suspects should volunteer information to the police, it is unlikely to accept poor advice to make no comment as a ground of appeal.

The courts have expressed their expectation that suspects will co-operate with police questioning. There is, however, no reciprocal obligation on the police to disclose their case to suspects or their advisers. Contrary to early expectations, and indications from the Court of Appeal, ${ }^{116}$ inadequate police disclosure does not justify the exclusion of a no-comment interview; rather it should be left to the jury to consider the reasonableness of the advice. ${ }^{117}$ Because representatives are unsure of the risks of advising no comment if the police refuse to disclose their case, some said that they may advise the client to 'say something and stop the interview if you are not too sure',118 or say that they will intervene if the police introduce undisclosed material. There is a danger, of which officers are well aware, that the suspect may have answered before the adviser can respond:119

We were having a lot of interviews stopped, 'I need a consultation with my client' and to be honest, I'd rather do that, I'd rather go into an interview and say something and the solicitor knows nothing about it. I mean, it's a particularly selfish way of looking at it, I suppose the suspect, nine times out of ten has answered your question before the solicitor says 'Oh, hang on a minute.'120

It cannot be fair that evidential significance attaches to the suspect's decision whether or not to reply in interview, when this decision must be made without full knowledge of the police case. Without disclosure, there can be no balance in the interview, as legal representatives have no means of checking the veracity of the police account, or of determining the lawfulness of the arrest, detention and questioning. A no-comment interview was one of the few sanctions or negotiating ploys available to legal representatives if they thought that the police were on a 'fishing expedition', had acted improperly, or were refusing to disclose their case. The CJPOA restricted this means of negotiation, which has circumscribed further the benefits of legal advice. ${ }^{121}$ Some solicitors have tried to avoid inferences by submitting a prepared statement before a no-comment interview. If this gives full details of the defence then no inference should be drawn. ${ }^{122}$ The Court has warned that inferences may be drawn if a more detailed or inconsistent account is given at trial ${ }^{123}$ and cautioned that this 'may prove to be a dangerous course for an innocent person who subsequently discovers at the trial that something significant has been omitted'. ${ }^{124}$

Bucke et $\mathrm{al}^{125}$ found a drop in the number of suspects refusing to answer all questions from 10 per cent before the CJPOA to 6 per cent afterwards. The Court of Appeal has shown little sympathy for the difficulties the CJPOA presents for legal advisers and has failed to recognise that the safeguards provided at trial, such as allowing inferences to be drawn only once the prosecution has established a prima facie case, do not apply when the suspect and solicitor actually make their decisions. The ECtHR has sought gently to

116 Roble (n 98). See R J Toney, 'Disclosure of Evidence and Legal Assistance at Custodial Interrogation: What Does the European Convention on Human Rights Require?' (2001) 5 E\&P 39, 53-54.

117 Argent (n 96); R v Imran and Hussein [1997] Crim LR 754.

118 Solicitor D13/ii.

119 Detective Constable A5.

120 Detective Constable A3.

121 Jackson (n 38) 160.

122 See Crown Court Bench Book (n 74).

$123 \mathrm{R} v$ Knight [2004] $1 \mathrm{Cr}$ App R 9, CA; followed in R v Turner (Dwaine) [2004] 1 Cr App R 24, CA.

124 Turner (n 123). See also R v Faisal Khan Mobammad [2009] EWCA Crim 1871.

125 Bucke et al (n 13). 
reinforce the 'paramount importance'126 of legal advice in ensuring fairness to suspects at the police station, acknowledging that the provisions place the accused in a 'fundamental dilemma'. ${ }^{127}$ This led to the CJPOA being amended so that inferences can no longer be drawn from a suspect's failure to answer questions in interview if legal representation has been denied. ${ }^{128}$ What both the ECtHR and Court of Appeal have failed to recognise, however, is the fundamental dilemma that the legal representative now faces. Advisers now have to assess not only the current strength of the police case, whether or not the police are willing to disclose it, but also predict its potential strength should the case come to trial. Advising suspects to answer questions may provide the missing information that allows them to be charged; whereas recommending no comment may result in inferences being drawn that strengthen a weak prosecution case to the required standard of proof should the case get to trial. The risk of invoking inferences has diminished the protective function of the lawyer and undermined their bargaining power to ensure the fair and legal treatment of clients at the police station. This inhibits the defence from testing the police case and in practice may allow the police to question the suspect on dubious legal authority. It appears that the Court now considers the role of the adviser should be to facilitate the expeditious processing of their clients; an advantage for the legal system, but not necessarily in their clients' best interests, and an interpretation of the CJPOA which goes far beyond that anticipated when it was enacted. ${ }^{129}$

\section{A 'fundamental dilemma' v a 'fundamental condition': how inferences trumped legal professional privilege}

Part one of this article suggested how the CJPOA led to further legislative encroachments on defendants' rights; this section explores how the Court of Appeal has allowed the legislation to encroach upon legal professional privilege, a principle it had hitherto defended robustly. Communications between lawyer and client have a special legal status, preserving their confidentiality in order to encourage full and uninhibited disclosure. 130 Once established, no exception should be allowed to the absolute nature of this privilege. ${ }^{131}$ In a ringing endorsement, the House of Lords described legal professional privilege as a fundamental right, protected by the ECHR and held:

... a man must be able to consult his lawyer in confidence, since otherwise he might hold back half the truth. The client must be sure that what he tells his lawyer in confidence will never be revealed without his consent. Legal professional privilege is thus much more than an ordinary rule of evidence, limited in its application to the facts of a particular case. It is a fundamental condition on which the administration of justice as a whole rests. ${ }^{132}$

The leading case on privilege of Derby Magistrates' Court ${ }^{33}$ involved a request for privileged information that might yield potentially exculpatory evidence in a murder trial.

126 Murray (John) v UK (1996) 22 EHRR 29, 67.

127 Ibid.

128 S 58 Youth Justice and Criminal Evidence Act 1999. If access to legal advice is denied, then suspects should be given the pre-CJPOA caution (PACE Code of Practice C, Annex C).

129 S Cooper, 'Legal Advice and Pre-trial Silence: Unreasonable Developments' (2006) 10(1) E\&P 60-69, 69.

130 Campbell v UK (1993) 15 EHRR 137. Legal privilege is defined in s 10 of PACE, which gives effect to the common law position ( $\mathrm{R} v$ Central Criminal Court exp Francis \& Francis [1989] AC 346, 392). See J Auburn, Legal Professional Privilege: Law and Theory (Hart Publishing 2000).

131 R v Derby Magistrates' Court exp B [1996] AC 487, HL; and B v Auckland District Law Society [2003] 2 AC 736, PC.

132 Derby Magistrates' Court (n 131) 507, emphasis added. For a critical review of this decision, see C Tapper, 'Prosecution and Privilege' (1996) 1(5) E\&P 20.

133 Derby Magistrates' Court (n 131). 
Notwithstanding the importance of this claim, protection of privilege was regarded as 'so fundamental that it "trumps" . . . any claim of a defendant to show his innocence by relying on material protected by another's privilege'. ${ }^{134}$ Whilst acknowledging that the right was not absolute, their Lordships declined to undertake a balancing exercise, reasoning that 'once any exception to the general rule is allowed, the client's confidence is necessarily lost'. The Court noted that Parliament had not addressed privilege and thus refused to erode it. ${ }^{135}$ In other cases it has held that the right to legal confidentiality cannot be overridden by general or ambiguous statutory words; an intention to override must be stated expressly or appear by necessary implication. ${ }^{136}$ In the CJPOA cases, judges have been markedly less robust in their defence of privilege. ${ }^{137}$

Many commentators assumed that legal advice would be a reasonable excuse for failure to mention facts at the police station. ${ }^{138}$ The Court thus had to reconcile preserving this fundamental condition with the risk of 'guilty' suspects exploiting legal privilege to avoid inferences from their silence. The manner in which it has done so appears rooted firmly in the post-CJPOA expectation that silence has to be justified, and is in contrast to its previous position. ${ }^{139}$ As discussed above, the Court gave the submission short shrift, fearing a 'coach and horses'140 would be driven through the provisions if this were allowed. A simple assertion of reliance on legal advice, without explanation, will be unlikely to avert inferences. Defendants who remain silent following legal advice now have to balance the risks of waiving privilege against the potential advantages of calling their adviser to explain the basis of their advice, or to rebut allegations of subsequent fabrication. This interpretation of the provisions has been held not to contravene Article 6 ECHR as the suspect experiences only the 'indirect compulsion' to waive privilege of being able to offer merely a bare explanation as a defence. ${ }^{141}$ In practice this amounts to little more than Hobson's choice, as suspects either have an unexplained silence from which inferences may be drawn, or they seek to explain this and have to waive privilege. Whilst the Court is concerned that the defendant should not 'have his cake and eat it', ${ }^{142}$ it would appear that the prosecution can and does enjoy the benefits of being able either to use potentially damaging disclosures from the suspect, or of inviting inferences from a suspect's silence.

The Court of Appeal sought to clarify the law on privilege in s 34 cases in Seaton. ${ }^{143}$ Having reviewed the relevant authorities, ${ }^{144}$ the Court reiterated that legal professional

134 R v Loizou [2006] EWCA Crim 1719, [40].

135 Derby Magistrates' Court (n 131).

136 R (Morgan Grenfell \& Co. Ltd) v Special Commr of Income Tax [2003] 1 AC 563, HL; and B v Auckland District Law Society (n 131).

137 The Court went on to interpret the Regulation of Investigatory Powers Act 2000, which contains no express provision about privilege, to permit the covert surveillance of meetings between defendants and their lawyers, without express Parliamentary authority (Re McE [2009] 1 AC 908). See Bar Council 'Bar Council: Private Legal Advice Must Be Protected', press release, 2 February 2012 <www.barcouncil.org.uk/mediacentre/news-and-press-releases/2012/february/bar-council-private-legal-advice-must-be-protected> accessed 27 June 2013.

138 Dennis (n 43) 17; R Munday, 'Inferences from Silence and European Human Rights Law' [1996] Crim LR $370-85$.

139 For a more optimistic interpretation see D Wolchover, 'Serving Silent Suspects' pts 1-3 (2011) 175 Criminal Law and Justice Weekly 71-72, 86-88, 104-06.

$140 \mathrm{R} v$ Beckeles [2004] EWCA Crim 2766; [2005] 1 WLR 2829, [43].

141 Condron v UK (n 84) 22.

142 Bowden (n 72) 831.

143 R $v$ Seaton [2010] EWCA Crim 1980, [43].

144 R v Wilmot (1989) 89 Cr App R 341; Condron (n 65); Bowden (n 72); R v Wishart [2005] EWCA Crim 1337; and R v Loizou [2006] EWCA Crim 1719. 
privilege is of paramount importance and that there is no question of balancing privilege against other considerations of public interest. In the absence of waiver, no question can be asked which intrudes upon privilege. The mere assertion by the accused that the reason for not answering questions was on legal advice does not amount to waiver. Yet its judgment was not wholly consistent. Of greatest significance was the Court's finding that the previous cases had misinterpreted Wilmot. ${ }^{145}$ The Court held that a defendant who adduces evidence of the content of, or reasons for, such advice, beyond the mere fact of it, does waive privilege, at least to the extent of allowing cross-examination about what the solicitor was told and whether this can be the true explanation for the suspect's silence. ${ }^{146}$ Once this happens, the legal representative can be asked about any other reasons for the advice, including whether it was for tactical reasons, the nature of the advice, and the factual premise upon which it was based. ${ }^{147}$ Where a defendant does not waive privilege by calling the solicitor to give evidence, the judge may direct the jury:

You have no explanation for the advice in this case. It is the defendant's right not to reveal the contents of any advice from his solicitor or what transpired between himself and his solicitor. At the same time he has a choice whether to reveal that advice and thereby reveal all that transpired between himself and his solicitor. ${ }^{148}$

If the comment is fair, another party can comment upon the fact that the solicitor has not been called to confirm something which, if true, could be confirmed easily. This does not waive privilege entirely; the test is fairness, or the avoidance of a misleading impression, or both.

Some of the cases relating to legal privilege have turned on quite technical legal questions regarding waiver. What has not been addressed by the courts is the potentially deleterious effects of using the defendant's legal representative, the person supposed to 'protect and advance the legal rights of their client' potentially to discredit them. The Court in Seaton raised the possibility of the Crown being able to call the defence solicitor to give evidence on these matters, albeit limited to the point in issue. It noted the danger of the solicitor 'trespassing inadvertently beyond the part of the communications which the defendant had opened up' and that 'in reality that would not be practicable', but focused on the logistics of such an exercise rather than the potential ramifications of such an action. Even if the cross-examination were confined to whether or not the defendant had told the solicitor the relevant fact that had not been revealed in interview, it would seem likely that defendants might lose confidence in the confidentiality of proceedings and this might affect the frankness in future cases of the 75 per cent who are repeat offenders. ${ }^{149}$

The possibility of the legal representative having to give evidence has introduced tensions into the solicitor-client relationship as advisers now consider the ramifications for themselves as well as, or perhaps instead of, their clients. ${ }^{150}$ There was a deepening concern that 'a barrier will be created between suspect and adviser: the whole purpose of independent legal advice and the basic principles of adversarialism will be undermined'. ${ }^{151}$ Suspects should sign the advisers' attendance notes to confirm they have made the decision to remain silent but, even before the courts required this, ${ }^{152}$ in order to protect themselves

145 Wilmot (n 144).

146 R v Seaton [2010] EWCA Crim 1980, approving Bowden (n 72).

147 Bowden (n 72).

$148 \mathrm{R} v$ Bresa [2005] EWCA Crim 1414, [49].

149 Criminal Justice Statistics Quarterly Update to September 2011 Ministry of Justice Statistics Bulletin 2012.

150 Cape (n 21).

151 Leng (n 17) 127.

152 Criminal Practitioners Newsletter (2006) (n 106). 
from criticism at trial, some firms had produced all-encompassing disclaimers for their clients to sign:

I [name] have been advised by my Solicitors, [name and address of firm], that an adverse inference may be drawn if I make no comment in an interview. Nevertheless I wish to have a 'no comment' interview and fully understand the consequences that may subsequently arise. Signed Date Name (please print)

Some solicitors appear more concerned with protecting their own positions than acting solely in their clients' interests:

They're thinking I'm there to advise them. I say 'it's got to be your decision at the end of the day'. I don't want to get the blame... I'm fearful of that. That's why I try to put the guilt trip on the client as it were. I let him decide. More often than not, I get him to sign something. ${ }^{154}$

It's so rare that you advise them to remain silent, that you make sure you've got concrete reasons for doing it, because you always think 'I may have to take the stand about this one day. 155

Few legal representatives interviewed had given evidence as to why they had advised a nocomment interview. A minority were concerned about the prospect, through fear ('It scared the living daylights out of me'); ${ }^{156}$ a belief that solicitors should not have to justify their advice; ${ }^{157}$ or because of the financial implications of losing a client. ${ }^{158}$ (A solicitor cannot represent a client and be called as a witness in their cause, so, in the magistrates' court, new representation would have to be sought which is not in the solicitor's interests.) Barristers may also experience conflict from the commercial pressure not to alienate the solicitors who give them work:

It's such a tight community ... one day you can be prosecuting, you know [X]'s client and the next day, you're acting on his behalf, and the day before you called him an absolute wazzock! [idiot] ${ }^{159}$

Whilst the Court of Appeal has observed the niceties about legal privilege, the change in approach it has developed through its interpretation of the CJPOA provisions has facilitated incursions into another fundamental protection for defendants. Defence solicitors having to testify about the advice they gave, in however restricted a form, allows the prosecution to probe further the 'genuineness' and 'reasonableness' of the suspect's decision to make no comment. It is not known what effect it may have on the jury of seeing a defence representative cross-examined, but it seems likely to attract a disproportionate amount of the jury's attention compared to its evidential value. ${ }^{160}$ In a most literal way, defence solicitors may now have to justify under oath their decision to advise no comment.

\section{Conclusion}

The rhetoric around the CJPOA advocated rebalancing a system that was described - rather than demonstrated - as being too favourable to criminals. As well as facilitating further

153 Firm J14.

154 Solicitor D13/ii.

155 Solicitor A13/iii.

156 Solicitor A12/ii.

157 Solicitor A13/iii.

158 Solicitor B2/i.

159 Barrister B1.

160 Birch (n 16) 786. 
legislative encroachments by Parliament, it appears to have changed the culture in which defendants are tried. Many of the changes were criticised as being inappropriate to an adversarial system, leaving the accused with the worst of both worlds: being investigated in a semi-inquisitorial manner, the results of which are then deployed in an adversarial context. ${ }^{161}$

The CJPOA was founded on the contention that 'criminals,' abetted willingly or witlessly by their lawyers, were exploiting the right of silence to evade justice. Such a view paid scant regard to the research or to the consequences for the presumption of innocence and the burden of proof. The protections offered to suspects in custody by PACE are undoubtedly an improvement on the common law but the suggestion that the right to legal representation gave suspects an unfair advantage over the police was demonstrably flawed. Only a minority of suspects was legally represented and the quality of that representation was variable. The police are gatekeepers of suspects' rights and can circumvent or minimise the benefits of many of these protections. The refusal to answer police questions was hitherto the only immediate sanction that suspects and legal advisers had in response to the police either abusing their powers or acting beyond them; this now carries evidential risks. More suspects now have access to legal advice but their representatives are able to do less. The protective benefit of legal advice, a fundamental requirement of a fair trial, is devalued by the quandary in which legal representatives are now placed of having to choose between the risks of allowing suspects to answer questions and potentially inculpate themselves; or of facing adverse inferences, should prosecutions follow. Whilst the direct effects of the Act have been limited by the relatively small numbers of suspects making no comment, its effects upon legal representatives have shifted the balance of power in custodial interrogation further in favour of the police.

The Court of Appeal appears to have absorbed the crime-control assumptions underlying the CJPOA. In its interpretation of the Act, it has shown increasing impatience with the idea that suspects should not have to facilitate the prosecutorial process and has disapproved of solicitors representing their clients in an adversarial manner. It has refused most attempts to circumscribe the effects of the CJPOA, even when encouraged to do so by the ECtHR. It has shown little understanding of the difficulties that solicitors face in their work and has sought to restrict their role in a manner which arguably contravenes the intentions of Parliament. The Court of Appeal has made some attempt to limit the extent of the waiver of privilege, but solicitors are now acutely aware that they may have to give evidence about their advice, thus losing the client if the case is heard summarily, and they fear damaging their reputation with the client if their advice is deemed to be wrong, and risk damaging their client's case if their testimony is not well-received. The Court of Appeal has pursued the idea that nocomment interviews are not a legitimate tactic in an adversarial situation, but rather are unnecessarily obstructive of justice. Jackson observed that the CJPOA provisions have made police station questioning part of the trial process; ${ }^{162}$ in its interpretation of the Act, the Court of Appeal has gone further and imported the traditional suspicions that police officers have of lawyers into the courtroom to the detriment of defendants, legal advisers and to two fundamental principles of justice. Twenty years later the right of silence is little discussed but its effects continue to reverberate.

161 Cape (n 115).

162 Jackson (n 22). 
